\title{
An Empirical Investigation of Performance of Logistics and Economic Growth Nexus in Sub-Saharan Africa: Panel Data Approach
}

\section{Demilie $\mathrm{BH}^{*}$ and Meron Z}

Department of economics, Adigrat University, Adigrat, Ethiopia

\begin{abstract}
The paper investigates the Performance of logistics and economic growth nexus in Sub-Saharan Africa. Accordingly, it is conducted using a panel data analysis on the basis of 19 sub-Saharan African countries from 2007 to 2014 . Though the performance of Logistics is in its grass root level, it brings a meaningful change on economic growth. Inflation has a significant and negative effect on growth. However, financial development, proxied by private credit and broad money supply, is insignificant. The result confirms continues human development and an efficient, liberalized and well developed financial system are needed to bring rapid economic growth.
\end{abstract}

Keywords: Logistics performance; GDP; Sub-Saharan countries

\section{Introduction}

Enhancing supply side chains particularly logistics is more effective in facilitating trade than the abolition of trade barriers. This is because of the fact that improvement in supply side chain could contributed for both consumers and producers via minimizing cost of delivery of goods and services. Efficient logistics enables Border agencies to take a comprehensive approach towards border management to reduce duplication and delays [1].

Logistics facilities are one of the most important strategic sectors of different nations and they are contemporaneous issues in the world wide. Production and distribution of goods and services are subject to development of logistics within the supply chain. Accordingly, Ismail [2] reveals the positive and significant effect of logistics' performance on economic growth. Logistics have a considerable contribution in facilitating education, health and all other development related issues through investments and improvements in supply side chains.

Logistic is considered as an important way of making interference to improve the international trade services. Therefore, improvement in efficiency of logistics sector increases the competitiveness of a country and thus it appears to be an important determinant of growth and development. Pinar [3] reveals the existence of positive relationship between developments in the logistic sector and economic growth.

Overcrowding in ports is associated with delays and extra time of voyage and dwell of ships and cargo at the port, which occur due to inefficiency of Logistics and supply chain. Consequently, problems in the port, related with efficiency of logistics, results in extra costs and disruption of trade and transport agreements. Usman [4] argued that the problem of overcrowding in African ports emanates from either planning, Regulation, capacity, efficiency or a combination of these.

Moreover, research works by Coolin [5] conforms that logistics sector is taking centre stage and recognized as key to stimulating trade, helping business efficiency and supporting economic growth. It is also vital to the nation's competitiveness and connectivity with the rest of the world [6].

Quality of logistics in the exporting and partner-country can have an important impact on bilateral [7].

Literatures are showing that economic growth and the pass of the nation is partially subject to the performance of logistics sector. Therefore, in the world of globalization, improving efficiency of logistics is taken to be a primary issue while struggling against poverty in sub-Saharan African countries. However, still little is known about the correlation between economic growth and performance of logistics. Therefore, this paper is designed to analyze the direction and magnitude impact of logistics performance on economic growth using a panel data analysis.

\section{Model Specification}

In consistent with different literatures, the writer used RGDP, measured in US dollar, as a proxy for Economic growth and the model is developed based up on the endogenous growth theory framework.

Since Logistics includes a wide range of activities which contains transformation and distribution from raw material source of goods to end market. Therefore, it is obvious that improvement in logistics performance enhances factor productivity and efficiency and hence logistics is taken to be a determining variable in the endogenous growth model.

Accordingly economic growth is subject to human capital (HC) and logistics performance index (LOG) and the mathematical model can be written as:

$$
\operatorname{LnRGDP} P_{t}=\beta_{0}+\beta_{1} \operatorname{LnHc_{t}}+\beta_{2} \operatorname{Ln} \log { }_{t}
$$

Moreover, the size and depth of the financial system reflects the size of savings and investments. Large financial systems reduce the financial constraints for credit. Therefore, in one or other round development in financial sector is the bottle neck of growth and hence in this study financial sector development is also taken as a key variable to determine the pass of growth.

Financial development can be measured by the ratio of liquid liabilities to GDP, the ratio of credit to private enterprises to GDP, the

*Corresponding author: Demilie $\mathrm{BH}$, Department of Economics, Adigrat University, Adigrat, Ethiopia, Tel: +251 948870000; E-mail: demilie604@gmail.com

Received July 28, 2016; Accepted October 17, 2016; Published October 21, 2016

Citation: Demilie BH, Meron Z (2016) An Empirical Investigation of Performance of Logistics and Economic Growth Nexus in Sub-Saharan Africa: Panel Data Approach. J Glob Econ 4: 221. doi: 10.4172/2375-4389.1000221

Copyright: @ 2016 Demilie $\mathrm{BH}$, et al. This is an open-access article distributed under the terms of the Creative Commons Attribution License, which permits unrestricted use, distribution, and reproduction in any medium, provided the original author and source are credited. 
ratio of assets of commercial banks to the sum of commercial banks assets plus assets of central banks. Moreover, Saci used the ratio of commercial bank assets plus central bank assets, credit issued to private sector to liquid liabilities, domestic credit to the private sector to GDP, the ratio of liquid liabilities to GDP, value traded ratio, number of listed companies and the ratio of broad money and narrow money as a proxy indicator of financial development.

In this study, we used logistic performance index computed by World Bank and also we stick to two proxy variables for financial development, due to data related problems in the region, the ratio of broad money supply to GDP (M2) and domestic credit to private sector (DCP). Lastly to capture the macroeconomic uncertainties, inflation (INF) variable is included as an explanatory variable and the estimable model is developed as follows.

$$
\operatorname{LnRGDP} P_{i t}=\beta_{0}+\beta_{1} \operatorname{LnH} c_{i t}+\beta_{2} \operatorname{LnLog}{ }_{i t}+\beta_{3} \operatorname{Ln} \operatorname{LnM} 2_{i t}+\beta_{4} \operatorname{LnDCP} P_{i t}+\beta_{5} \operatorname{Inf} f_{i t}+u_{t}
$$

\section{Result and Discussion}

In this part we present the analysis and result of the panel data across the 19 sub-Saharan African countries. The data is obtained from World Bank development indicators and international monetary fund (IMF) for from 2007 to 2014. On average, the logistics performance index is still in its grass root level. However, it seems sounding that over time there is progressive improvement in the logistic performance index.

A nation with higher the performance index the higher the GDP statistics and hence we can argued that partly a nation's economic performance is subject to and determined by the performance of logistics and supply chains.

Since one can use either fixed effect or random effect estimation techniques of panel data analysis depending on the assumption given to endogeniety problem. However, we have conducted a houseman test to use either of the techniques. Accordingly, accepting the null hypothesis is a guarantee for usage of random effect otherwise fixed effect (Table 1).

The test summary reflects random effect estimation is better than fixed effect method and hence we used random effect estimation technique to obtain the following result (Table 2).

Logistics facility is an effective means of promoting trade and regional integration. Sub-Saharan African country's logistics

\begin{tabular}{|c|c|}
\hline$\chi^{2}$ Statistic & Probability \\
\hline 0.720258 & 0.9488 \\
\hline
\end{tabular}

Table 1: Hausman Test

\begin{tabular}{|l|c|c|c|c|}
\hline Variable & Coefficient & Std. Error & t-Statistic & Prob. \\
\hline LnLog & 0.0093 & 0.0036 & 2.583 & $0.029^{\star *}$ \\
\hline INF & -0.560 & 0.186 & -3.0107 & $0.002^{\star * *}$ \\
\hline LnHc & 0.09378 & 0.05030 & 1.864 & $0.079^{*}$ \\
\hline LnM2 & 0.321 & 0.401 & 0.8004 & 0.324 \\
\hline LnDCP & 40.71083 & 91.62035 & 0.444343 & 0.6582 \\
\hline C & 15547.09 & 24004.77 & 0.647667 & 0.5193 \\
\hline
\end{tabular}

R-squared $=0.533 \mathrm{DW}=1.782040$

Adj. R-squared $=0.504$ F-statistic $=8.483718\left(0.00701^{* * *}\right)$

Note: The result is from eviews 7 software packages and * ${ }^{* *}$ and ${ }^{* * *}$ respectively stands for significance at $10 \%, 5 \%$ and $1 \%$, respectively. The diagnostic tests like DW and F- statistics shows absence of serious problems related to the model. Adj. $R$ squared of about 0.504 reveals about $50 \%$ of the variation in the dependent variable is well explained by the model or variables involved in the model.

Table 2: Dependent Variable: LnRGDP. performance is too small to bring the intended purpose and majority of them are land locked nations. Improvement in performance of logistics can increase efficiency and hence contribute significantly to reduce unit costs.

Logistics give the opportunity to reach everywhere around the world and get the opportunity of market access for goods and services for both production and consumption. Logistics determining factor in enhancing of overall economic growth of nations.

A logistics service is a key to increase flows and reduce unnecessary delays and overcrowded in stores. Improvement in logistics performance acts as a pulling factor for foreign direct investment, trade, tourism, human development and hence it has a multidimensional impact on the smooth running of economy.

Macro-economic uncertainty, inflation, has a negative effect on economic growth. It may because of the fact that inflation decreases real value of investment and hence investors may retreat from investment at sever inflation level which have a negative consequences on nations' growth pass. In line with economic theories, human capital has a positive and significant impact on economic growth in these countries.

The result reveals insignificant effect of financial development on economic growth. Since the study considers broad money supply percentage of GDP (M2) and domestic credit to private sector as percentage of GDP as a proxy of financial development, both M2 and private credit are still insignificant to bring a sustainable change on growth. It may be due to underdeveloped, non-liberalized and inefficient financial system in these countries. Moreover, the weak financial institutions may create rooms for misallocation of resources which leads to poor economic growth or may fail to bring the predetermined goal of accelerated growth. Financial development fails to raise economic growth via channel of increased investment due its underdeveloped and inefficient financial institutions.

\section{Conclusion and Policy Implications}

The study is conducted using a panel data analysis on the basis of 19 sub-Saharan African countries from 2007 to 2014. Logistics and human capital are growth enhancing variables whereas inflation has a negative effect on growth. That is increase in performance of logistics can bring tremendous influence on the development of national economy. However, financial development, proxied by private credit and broad money supply, is insignificant. The result confirms continues human development and an efficient and healthy financial system is needed to put the developing countries on the path of rapid economic growth. Moreover, still there is room for improving logistics performance in the regions.

\section{References}

1. World Economic Forum (2013) Outlook on the Logistics \& Supply Chain Industry

2. Ismail K (2012) The role of logistics in regional development

3. Pinar H (2015) The Impact of Developments in the Logistics Sector on Economic Growth: The Case of OECD Countries. Financial Issues.

4. Usman G (2015) Consequences of Port Congestion on Logistics and Supply Chain in African Ports. Developing countries studies.

5. Coolin D (2014) The Logistics Report

6. Alberto B (2013) Logistics and exports

7. Rodrigue JP (2012) The Benefits of Logistics Investments: opportunities for Latin America and the Caribbean. Inter-American Development Bank. 